To appear: Essays in Philosophy, volume entitled "Philosophy's Future." Probably 2011. Comments welcome.

\title{
There Is No Progress in Philosophy
}

\author{
Eric Dietrich \\ Philosophy Dept. \\ Binghamton University \\ Binghamton, NY \\ dietrich@binghamton.edu
}

\begin{abstract}
Except for a patina of twenty-first century modernity, in the form of logic and language, philosophy is exactly the same now as it ever was; it has made no progress whatsoever. We philosophers wrestle with the exact same problems the PreSocratics wrestled with. Even more outrageous than this claim, though, is the blatant denial of its obvious truth by many practicing philosophers. The No-Progress view is explored and argued for here. Its denial is diagnosed as a form of anosognosia, a mental condition where the affected person denies there is any problem. The theories of two eminent philosophers supporting the No-Progress view are also examined. The final section offers an explanation for philosophy's inability to solve any philosophical problem, ever. The paper closes with some reflections on philosophy's future.
\end{abstract}

\section{How Philosophy is like Science}

I'm a professor in a philosophy department. Most of my philosophical colleagues study ethics of one sort or another. We have in our department several consequentialists, a couple of deontologists and moral essentialists, a couple of virtue ethicists, and a few relativists. It is a commonplace that these views, at least in certain well-known formulations, are incompatible with each other. Certainly, most of my colleagues believe this. Most also believe that he or she is right. Since they also believe in theory-incompatiablism, they believe that their colleagues are wrong. The consequentialists (a group to which I do not belong) are particularly 
vociferous (no doubt just by chance). They passionately and earnestly explain to the rest of us that we are wrong, and they give us arguments both old and new to get us to change our views. We never do.

This is not to say that their arguments don't affect us. Like philosophers everywhere and of every stripe, we nonconsequentialists are strongly affected by our colleagues' arguments for consequentialism: they cause us to draw distinctions and find false premises and errors in our colleagues' reasoning. Of course, when we point these out, the consequentialists, like us, don't change their minds, they muster even more resolve and begin afresh.

Religion is also important in my department. Here matters are even more pointed, which is obvious from the fact that discussions about religion are far more polite than discussions about ethics. The theists think that the atheists are benighted, and vice versa. The Buddhists think both are sadly confused, and will only lose their confusion after many more cycles of death and rebirth. Since religions carry robust ontological commitments, the disagreements here about who's right and who's wrong are disagreements about the actual structure and content of the universe; they are disagreements about what kind of universe we live in. Arguments here are even more inefficacious than the ethical arguments discussed above.

These two cases -- ethics and religion -- are local instantiations of the way philosophers behave and have behaved since philosophy first appeared in humankind, which is probably contemporaneous with the emergence of language. Philosophers strongly disagree with each other, arguments rarely change any philosopher's mind (though sometimes arguments awaken a philosopher from his or her dogmatic slumbers), and they think the other is wrong and has made mistakes, rather than thinking that each other merely has a different take on the relevant facts. 
In thus behaving as they do, philosophers are acting almost exactly like scientists (and mathematicians). To see this, compare the situation in my department with the one across campus in the biology department. We have, at Binghamton University, a well-known biologist - David Sloan Wilson - who has for decades developed and argued for an important addition to the current theory of evolution: group selection theory. In group selection theory, selection pressures act not only on individuals (or genes), but also on groups of similar individuals, called trait groups. Wilson uses group selection to explain such things as the evolution of altruism and cooperation, for which group selection works quite nicely and apparently better than models based on gene selection. Wilson's view is more complicated than this brief description; for example, group selection is but one part of his larger theory called multilevel selection theory, which posits selection occurring at several different levels: gene, cell, organism, group (see, Sober and Wilson, 1998; Wilson, 1975; Wilson and Sober, 1994; and Wilson and Wilson, 2008). Nevertheless, this will do for our purposes.

Group selection is roundly rejected and even savagely attacked by the likes of Richard Dawkins and Daniel Dennett who reject it as either wrong or at best inconsequential (see, e.g., Dawkins, 1994, and Dennett, 2006). Group selection was banned from evolutionary biology back in the late 1960s mostly due to the late George Williams (Williams, 1972) -- the reasons are complex and sociological rather than scientific. But thanks to David Wilson and other biologists like him, group selection is making a comeback and finding a home in evolutionary theory. Dawkins and Dennett remain unpersuaded by Wilson's arguments. Wilson thinks they're wrong; they think he's wrong. For every argument Wilson musters, Dawkins and Dennett gear up their distinction-making and fault-finding in order to refute Wilson, and vice versa. One is strongly reminded of the old saw "Scientific debates are won only when the combatants die and a new generation comes of age adopting the new theories." If group (and multilevel) selection theory do eventually win, it will be because a new generation of biologists embrace them. 
It is remarkable how common this is in science. Einstein apparently went to his grave believing that quantum mechanics was wrong (even though he helped create it). Henri Poincaré, Leopold Kronecker, L. Brower, and L. Wittgenstein went to theirs believing that Georg Cantor's theories of transfinite numbers were not just wrong, but "a grave disease," to quote Poincaré. Though few in number, legitimate scientists to this day disbelieve evolutionary theory, preferring instead some sort of creation-by-intelligent-agent(s) theory. No doubt they will go to their graves maintaining such beliefs (and vice versa for evolutionists).

There are counterexamples, of course. Robert Bakker's theory that dinosaurs were warm-blooded, fast, and smart is now (with some variation) the received view, and it has become the received view in his lifetime. There is an appropriate and expiating irony here though: Bakker refuses to accept the asteroid/comet impact theory of the extinction of the dinosaurs, and this despite the 2010 publication in Science of a major paper strongly supporting the theory (Schulte, et al. 2010).

So, no one can convince one's opponent. All one can hope to do is convince the next, younger generation. Good theories, better theories, do just this. This behavior even probably makes sense, in the long run, for if we surrendered our cherished scientific theories too easily, we would not be sufficiently testing and stressing our theories for them to be legitimately awarded the coveted honorific: True. Thus does science lurch forward.

But what of philosophy? It clearly does look a lot like science here: no one can convince one's opponent, etc. etc. Does it also thus lurch forward?

No, it does not. 


\section{How Philosophy differs from Science}

Philosophy does not even stumble forward. Philosophy does not move forward at all. It is the exactly the same today as it was 3000 years ago; indeed, as it was from the beginning. What it does do is stay current; philosophers confuse this with advancing, with making progress. Staying current is not moving forward any more than staying up on the latest fashions or music is movement toward greater social justice.

I know this claim of mine strikes philosophers as obviously false, crazy, and outrageous. I get two kinds looks. One kind is one of utter confusion, as if I'd just sincerely asserted "One plus one equals three." The other is one of disgust as if I just sincerely asserted "Slavery is morally required."

"Look," you might say, in a spirit of trying to correct someone who thinks the moon is made of green cheese, "we all think slavery is immoral. In fact, we know it is. How is that not philosophical progress? How is that not progress in ethics which is branch of philosophy?"

I didn't say society doesn't progress. It does. We are now quite clear on the immorality of slavery. (More or less: though slavery is illegal in every country in the world, there are more slaves now than ever, and it is a billion dollar business). But philosophy didn't discover slavery's immorality. Philosophers weren't leading the charge against slavery when it was openly and commonly practiced. What happened was that political leaders and social activists (who weren't philosophers, but social activists) changed the way many thought about slavery to the point that attitudes changed, laws were enacted, and society and culture thereby changed. Philosophers had to catch up. This is true across the board in ethics. Except for a tiny handful of writings (Mill's on women's rights, for example; Locke on individual liberty and equal rights), philosophers were, and still are, not at the vanguard of any advance in morality and ethics. Philosophers didn't discover and start the push for animals rights, civil rights, rights for the disabled, the disenfranchised, they didn't 
push first, before everyone else, for increased diversity and respect for all humans and all life. They had to catch up to these ideas, and frankly, many are lagging quite far behind, still.

"But even so," you might reply, "philosophers now know that slavery is wrong. That's an advance, as you clearly admitted, so philosophy does advance."

Oh yeah ..., why is slavery immoral? No two philosophers will answer this the same way. Even within the consequentialists in my department there are several different explanations as to why slavery is immoral. In a deep and important sense, we don't know why slavery is immoral. We just know that it is. And knowing the latter is something many know. Philosophy's job -- if it even has one -- is to explain or say why slavery is immoral. And it hasn't done that. (Why it hasn't done that will be the topic of section 6.)

Society doesn't turn to its philosophers for a deeper understanding of moral and ethical issues. Society, when in desperate need, cannot ask its philosophers for help. "What should we do?" would be answered "Well, that depends. On the one hand, you might consider maximizing the good (in any of several different ways, using any of several definitions of "the good"), but on the other hand, you might consider that certain actions seem to some to be intrinsically wrong and others intrinsically good. And on the third hand, perhaps moral relativism is true after all. It's hard to say, really."

Here's a relevant quote from James Sterba (2005):

Ethics appears to be unlike other areas of inquiry. After all, we cannot find contemporary defenders of Ptolemy (c. 100-c. 170 CE), Copernicus (1473-1543), or even Isaac Newton (1642-1727), all claiming to have the best theory of the physics of celestial motion. Nor are there contemporary mercantilists or physiocrats, as there were in the 
eighteenth century, all claiming to have the best theory of economics. But we can find contemporary defenders of Aristotle (384-322 BCE), Immanuel Kant (1724-1804), John Stuart Mill (1806-1873), for example, all claiming to have the best theory of ethics. Of course, significant disagreements remain in other areas of inquiry, but the extent of disagreement appears to be much greater in ethics.

Sterba has hit the nail on the head. Clearly other philosophers also see that at least some branches of our chosen discipline don't make progress. The trouble with Sterba's view, however, is that it stops at ethics. Metaphysics and Epistemology, and all their subdisciplines, suffer the exact same fate (see also, McGinn, 1993 and Nagel, 1986). Very unlike any science, no part of philosophy advances. Philosophy is, except for some modernizing, exactly the same now as it has ever been. It has not progressed one iota.

\section{Aristotle Comes to the Twenty-First Century}

Imagine that Aristotle, as he's walking around the Lyceum, encounters a time-warp and pops forward to today, on a well-known campus somewhere in some English-speaking country, with the ability to speak English, dressed in modern garb, and that he doesn't become deranged as a result of all of this. Curious about the state of knowledge, he finds a physics lecture and sits in. What he hears shocks him. A feather and iron ball fall at the same rate in a vacuum; being heavier doesn't mean falling faster, something he doesn't understand. Aristotle along with the rest of the class is shown the experimental verification of this from the moon (from the moon?!?!?) performed by Commander David Scott of Apollo 15. The very same equations (equations?!?!?) that explain why an apple falls to the ground explain how the moon stays in orbit around Earth and how Earth stays in orbit around the sun (orbits?!?!?). He learns of quantum mechanics strangnesses. The more he hears, the more shocked he gets. Finally, he just faints away. He faints away again in cosmology class where he learns, for starters, that comets and meteors, and the Milky Way are not atmospheric phenomena, as he concluded. The Big Bang, 
relativity, the size of the universe, the number of galaxies, dark matter, and dark energy ... are all too much for him. In biology class, he learns that a living thing's potential, its matter, is not at all explanatory, as he thought, but instead learns of genetics and developmental biology. He also learns that his idea of spontaneous generation is just plain wrong -- not even close to being correct. He learns of evolution and the discovery that all of life on Earth is related. As the class continues, he again faints dead away.

After he comes too, he soberly concludes that this modern world, this advanced time, has utterly surpassed his knowledge and the knowledge of his time. He feels dwarfed by our epistemic sophistication. Sadly, he trundles off to a philosophy class -- a metaphysics class, as it turns out. Here he hears the professor lecturing about essences, about being qua being, about the most general structures of our thinking about the world. He knows exactly what the professor is talking about. Aristotle raises his hand to discuss some errors the professor seems to have made, and some important distinctions that he has not drawn. As the discussion proceeds, the metaphysics professor is a bit taken aback but also delighted at this (older) student's acumen and insight. Then Aristotle goes to an ethics class, where he learns of the current importance of what is apparently called "virtue ethics." He recognizes it immediately, but again, the professor seems to have left out some crucial details and failed to see some deeper aspects of the view. Aristotle raises his hand....

This story of Aristotle's return to philosophy no doubt is somewhat plausible to the reader (excluding, probably, the time-travel part). Perhaps it is no more than that or just barely that. But this is all I need. The fact that this story contains even a whiff of plausibility shows that the reader can discern a crucial difference between science and philosophy. From our twenty-first century perspective, we see that Aristotle was not even in the ball park with most of his scientific ideas, theories, and conclusions. His works in science are only of historical interest. But he is a giant to this day in philosophy. We can learn by reading his philosophical works. 
This pattern of ignoring old science but rereading over and over again old philosophy repeats throughout the histories of science and philosophy. Here's another case. Consider Einstein (1879-1955), Frege (1848-1925), and Wittgenstein (1889-1951). The works of the latter two philosophers are read closely to this day, not only by accomplished, professional philosophers, but in graduate seminars where their works are plumbed for deep truths. Yet, no physicists read Einstein's 1905 papers, even the one on Special Relativity, nor do they read his 1916 paper on General Relativity. Of course, both Special and General Relativity are still taught -they are regarded as the backbone of modern physics and cosmology. Having been tested thoroughly, Einstein's theories are currently regarded as true. But it is precisely because these theories are regarded as true that no one reads them in their original descriptions. Instead modern versions with much more perspicuous mathematics are taught and used. Since his theories are true, what Einstein actually said needn't be fought over. Frege's and Wittgenstein's theories and conclusions, on the other hand, are not regarded as true; they are regarded as interesting and important. So, of course, the originals would be read and examined... and fought over. For example, Kripke's interpretation of Wittgenstein (1982) caused strong debate, with many Wittgenstein scholars decrying Kripke's book and the ideas in it (e.g., McGinn, 1984; Baker and Hacker, 1984).

The exact same pattern emerges with Charles Darwin (1809-1882) and John Stuart Mill (1806-1873). Darwin's conclusions are regarded as true, so there's no need to agonize over what he actually said. Mill's conclusions are not regarded as true, but rather, interesting and important. So we do need to agonize over what he actually said.

In sum, though the relevant scientific texts are old, the theories, when true, aren't (truth doesn't age). So we teach the theories, which we update with better techniques. However, no philosophical theory is true, or at least no theory is regarded as true by significant and large majority of philosophers. So, we have no 
recourse but to agonize over and rehash what the philosopher said. In the case of philosophy, the texts remain "new," in the sense that they are still published and read.

What could explain this pattern of vast disparity in the histories of philosophy and science, in what the returning Aristotle experiences? Only one thing: Philosophy doesn't progress. Yes, it morphs and transforms to stay current. Our metaphysics today is not Aristotle's metaphysics. Ours is populated, for example, with possible worlds, whose existence is bolstered by a robust and large family of logics that Aristotle couldn't have imagined. Our metaphysics contains ideas like supervenience, which is used to explain, among other things, the relationship between mind and brain and the relationship between consciousness and brain. But more importantly, our metaphysics is for us. It is written in our language for us to communicate our twenty-first century ideas in. But that's all; that's the extent of the "progress". The ideas and theories are new or couched in modern language, but no real progress is made, none.

\section{Philosophical Anosognosia}

One might object that notions such as possible worlds, supervenience, and modal logic are definitely advances; they obviously represent progress. In fact, philosophy, across the board, contains many notions and concepts that are completely new and very useful. Aristotle didn't have these notions, these advanced and powerful concepts with which to explain the mind, the universe, and everything.

I must have received this objection dozens of times. What's astonishing about this objection is how lame it is while at the same time being ardently believed. If all these new notions represent advances, where's the true philosophical theories? Where's the deep and widespread agreement throughout the philosophical world about which theories are true? I have even been told by philosophers, as they narrow their eyes, furrow their brow, and get very serious, that theory $X$ is true. The problem is, and you, the reader, knows this is coming, that $X$ ranges not only over 
many different theories, but theories which are flatly incompatible. I've been told that Kant's theory of ethics (with some fixes) is true, and then been told that Mill's theory is (with some fixes). In all these cases, the theory $X$ that I' $m$ told is true, is the one the philosopher him- or herself happens to believe and work on (no surprise there).

How could the obvious truth that philosophy lacks true theories, or at least lacks theories that are widely regarded as true, be denied? How could the obvious truth that philosophy never progresses be so vociferously denied?

Anosognosia is a mental disability in which a person who suffers from another, primary disability denies that he or she does in fact suffer from the primary disability. Some cases of anosognosia are shocking in that the primary disability is conspicuous and large. For example, blind or paralyzed anosognosiacs will simply deny that they are blind or paralyzed.

Philosophers the world over suffer from anosognosia. Their primary disability is that they work in a field, a discipline, that never progresses, yet most of them get state money in the form of salaries. This creates cognitive dissonance and is apparently impossible to live with. So, they develop anosognosia and simply deny that philosophy never progresses. They assert that philosophy does progress, because, after all, we now know that... wait for it ... theory $X$ is true.

Philosophers also suffer from other mental disabilities. They suffer from the Illusion of Explanatory Depth. IOED is the universal error that all of us make in believing that we know more about something than we actually do. Example: Try explaining how a zipper works. Or a battery (see Rozenblit and Keil, 2002). Philosophers (qua philosophers) suffer from a particularly egregious form of this epistemic error: While holding a heavily marked-up and annotated copy of Aristotle's Metaphysics, a modern metaphysician will hold forth about modern metaphysical theory $X$ and why it is true, even while no one believes him. At least 
zippers actually work and there was a pre-zipper time -- they represent technological progress. And, and this is the key, at least someone somewhere can explain zippers fully and completely.

And finally, philosophers (qua philosophers) suffer from Illusory Superiority, a cognitive bias that causes people to overestimate their positive qualities. Again, philosophers suffer from an extreme version of this. Philosophy is essentially destructive. Whatever you believe, no matter how obvious or fundamental, no matter who you are, or where, or when, there's a good philosophical argument that your belief is false. There is no deep, foundational belief that philosophy cannot refute (not even Descartes' Cogito). Most who are susceptible to IS think they are above average, but philosophers think they are so superior that they claim to be the direct opposite of what they actually are: the Vandals and Visigoths of the intellectual world. Or, better: the incoming, Everest-sized asteroid streaking toward all that decent people hold dear.

\section{Philosophy and the Nosognosiacs}

Nosognosiacs know that they suffer from some ailment or disability ("nosognosiac" is a term of my coinage). As we've seen, there are some philosophers who do know that philosophy never progresses, or at least are wary of claims of significant progress. Two of the most distinguished are Thomas Nagel and Colin McGinn. Their seminal works on this topic are, respectively, The View From Nowhere (1986), and Problems in Philosophy (1993). Here, very briefly, are their theories.

Nagel argues that philosophical problems are intractable because of the contradictory interaction of two necessary and ineluctable points of view: the objective point of view and the subjective point of view. For example, from the subjective point of view, we seem to have freewill, but from the objective point of view, we seem to lack freewill, and instead be causally determined like every other physical thing. 
Science works on Nagel's view because it is only done from the objective point of view. The subjective point of view though real, is ignored in science: even when science studies consciousness -- the sine qua non of the subjective point of view -- it studies it from the objective point of view (to no great success, obviously). The relation between science's crucial property of being public and openly accessible is tightly tied to its being practiced only from an objective point of view.

McGinn argues that philosophical problems are intractable because of the way our minds function. Our minds are primarily for knowing about the world. They work best where there they can discern some domain of primitive elements the combination of which gives rise to complex aggregates or structures that supervene on the primitive ones. The problem is that philosophical problems are not amenable to such an understanding. All philosophy problems are tractable in principle, just not to us. It is as if we asked a turtle to run the 100 meter dash in under 20 (or even under 60) seconds. Or we asked a chimpanzee to figure out how to combine general relativity and quantum mechanics in a single testable theory.

Science works on McGinn's view because the bottom-up strategy our minds prefer is applicable to the ordinary world: physics, chemistry, biology, and even psychology do seem to work this way.

\section{Philosophy: a Riot of Relativism}

McGinn's and Nagel's theories seem different, but a closer examination of them reveals that they are variants of the same idea. From here, we will see that they in fact are contradictory.

Crucial to McGinn's view is that idea that though we cannot solve the problems of philosophy, they are in fact solvable, at least in principle (1993, chs. 8 and 9, esp. pp. 128ff and 135-156.). And this isn't mere logical possibility either, this is physical possibility (possible in this universe; indeed, he thinks aspects of our 
own brains have in fact solved some central philosophy of mind problems, but we cannot access said knowledge, pp. 135-143). Therefore, there are, in principle, a set of physically realizable epistemic, cognitive capacities can solve philosophy's problems. This set of capacities constitutes a point of view from which philosophy's problems can be solved. Humans just happen not to inhabit the right point of view, i.e., have the right cognitive capacities, to solve philosophy problems. Nagel's view is directly about points of view shifts. Therefore, both McGinn's and Nagel's theories of why philosophy doesn't progress are based on points of view.

Given this similarity, it is now easy to see that the two theories are contradictory. Nagel's theory says:

There are three points of view. From the subjective view, we get one set of answers to philosophy questions, and from the objective view, we get another, usually contradictory, set, and from a third view, from which one can see the answers of both the subjective and objective views, one can see that the subjective and objective answers are equally valid and equally true. Therefore, philosophy problems are intractable. Philosophy cannot progress because it cannot solve them.

McGinn's theory says:

There are two relevant points of view. From one, the human view, philosophy problems are intractable. From the other, the alien view, philosophy problems are tractable (perhaps even trivial; again, see ch. 8, op. cit.). The situation here is exactly like the situation with dogs and English. We easily understand it. Dogs understand only a tiny number of words, and seem to know nothing of combinatorial syntax. Therefore, though it is unlikely we can solve any philosophy problems, they are not inherently intractable. 
We see then, that Nagel thinks that philosophy is inherently intractable: any humanly intelligent, conscious being is going to be ensnared by philosophy, provided only that it considers any of it. And there exists a point of view from which this truth can be seen. McGinn denies this. He thinks that philosophy is only locally intractable. Alien beings could well find philosophy problems intuitively easy to solve. There exists a point of view from which philosophy problems are solvable.

Nagel and McGinn are of course doing metaphilosophy. Plausibly, metaphilosophy is philosophy. Therefore, we have here a paradigm case exhibiting the property philosophy has in common with science: two theorists disagreeing about their explanations (in this case, about why philosophy doesn't or can't advance). But since this is philosophy, we can predict that neither theory will ever win out, even in the minds of future generations.

But wait! Isn't this incorrect? If space aliens show up and give us the solutions to our philosophical problems, then McGinn will be proven right and Nagel wrong. But, McGinn denies that this can happen: we wouldn't understand their solutions. Again, think of giving dogs our solution to making dog toys (factories, synthetic, harmless fibers, plastic squeakers, etc.). They wouldn't get it, to put it mildly. And, in any case, the arguments are about what to believe now. Of course, we might wake up tomorrow with a sudden understanding of the freewill/determinism problem. But if we ask, today, what that understanding would be, we'd be doing philosophy and we'd get nowhere.

So Nagel and McGinn are doing philosophy, and accordingly we will never know which of their theories is correct, if either is. From Nagel's point of view, the subjective/objective divide is unbridgeable, and is the font of all philosophy and its intractability. From McGinn's point of view, there is a point of view from which the problems of philosophy are solvable, indeed, solved. 
We see from my couching the clash between Nagel's and McGinn's theories as a clash between points of view that Nagel's point of view theory generalizes: All philosophy problems, and indeed, anything that seems like a philosophical advance can be rendered as a clash between points of view on a specific issue. From one point of view, we get one answer, and from another view, we get a different, usually contradictory, answer. Nagel's theory restricts these points of view to subjective and objective ones, but that restriction can be relaxed.

For an example, consider a famous case from the history of philosophy. Quite some time back, it was thought that all necessary truths could be known a priori. So, if $a=b$ was a necessary truth, then it could known without any investigation of the world. But then a posteriori true identities like water $=\mathrm{H}_{2} \mathrm{O}$ which cannot known without investigating the world, must be contingently true. The notion of contingent identity was widely agreed to be correct, and found steady employment in the philosophy of mind, where it bolstered physicalism. In 1970, Saul Kripke changed all that by point out that contingent identities were usually nothing of the sort. Assuming that " $a$ " and " $b$ " are names of a certain kind (what Kripke called rigid designators - names that designate the same thing in all possible worlds), then $a=b$ has to be necessary. Usually, " $a$ " and " $b$ " are rigid designators. So usually identities are necessary; contingent identity is almost vanishing rare, according to Kripke. Hence, there must be necessary truths, e.g., water $=\mathrm{H}_{2} \mathrm{O}$, that can only be known $a$ posteriori. One argument Kripke used to make his case against contingent identity was this. Consider your desk. Fans of contingent identity were fond of saying things like "The desk could have been made out of ice; but it is not; it is therefore contingently true that your desk is made out of what it is, wood, let's say; whence there is a contingent identity here." But, as Kripke pointed out, this desk (here, you point to your desk) could not have been made of ice; this desk is made of wood. If your desk had been made of ice, it would not have been this desk. By using the demonstrative "this," Kripke was changing the point of view in the debate about contingent identity: he was forcing the reader to consider this very desk, rather than a desk considered only under the description "My desk." The Kripkean point of view 
(K) of this very desk, focuses the reader on the desk as an object in and of itself, rather than the desk as falling under some description as "My desk, at which I sit and type." From point of view $\mathrm{K}$, the desk is perceived independently of all descriptions, while from the description point of view, the desk is perceived under a description. Essentially, Kripke pointed out that fans of contingent identity were guilty of thinking only of things under a description and never as things as they were in and of themselves.

Kripke's point of view change had a huge impact on philosophy, but it is not a change between subjective and objective points of view such as required by Nagel's theory. Examples such as the Kripkean one are everywhere in philosophy, and are responsible for much of it. We can see, then, that there are more points of view change crucial to philosophy than those between subjective and objective points of view. The change between Nagel's and McGinn's is another example (for more on this example, see Dietrich and Hardcastle, 2004, esp. ch. 6). (I should point out that as compelling and important as Kripke's demolition of contingent identity was, since it was philosophy, contingent identity has made a come-back (see, e.g., Gibbard, 1975). To date, both approaches to identity are alive and kicking, naturally.)

Philosophy, then, emerges as a riot of relativism. Views that are flatly contradictory are equally plausible. All one has to do is adopt the right point of view to see first one answer to a philosophy problem and then, by adopting another point view, see a conflicting, second answer.

There is much more work to do on points of view, work that is required before the weirdness that is philosophy can be explained and understood. But we now know this much: In philosophy, clashing points of view are ineluctable, and their existence is the only truth. Thus philosophy cannot progress.

(Points of view don't go away when we do science. But all the relevant views belong to the same family, and thus belonging, cooperate, at least in the long run. It 
is quite hard to characterize this family. It is not just the family of objective points of view, though it is that. Public, repeatable, objective are terms that only partially characterize this family. I hope to have more to say about this in future.)

\section{He who understands me finally recognizes me as right ... and wrong}

In 6.54 - 7 of his Tractatus, Wittgenstein says,

My propositions are elucidatory in this way: he who understands me finally recognizes them as senseless, when he has climbed out through them, on them, over them. (He must so to speak throw away the ladder, after he has climbed up on it.)

What we cannot speak about we must pass over in silence.

Same thing here, and I'm as silent as Wittgenstein was. My explanation of why philosophy does not and cannot progress (clashing points of view are ineluctable in philosophy) is a bit of philosophy. So, of course it will not convince the anosognosiacs. And it won't even convince the nosognosiacs, like Nagel and McGinn, whose theories differ from mine (the union of those two sets is probably everyone but me). Nor will the truth of why philosophy never progresses ever be known.

Eons from now, after the humans are gone, perhaps points of view will remain. Perhaps powerful intelligences will still exist -- a sufficient condition for points of view. Perhaps they will exist elsewhere in the universe, perhaps we will have created our own descendents (Dietrich, 2007). Regardless, we can be certain of this: if points of view still exist, then so will philosophy -- the very philosophy we are wrestling with today, and the very philosophy we wrestled with all those centuries ago. 


\section{Acknowledgements}

I thank Zach Weber, Chris Fields, and David Chalmers for reading and commenting on previous drafts. Thanks to Zach and Chris for long and trenchant discussions on this topic. I also thank the participants of Binghamton University's April 2011 TEDX Conference for comments. 


\section{References}

Baker, G. and Hacker, P. (1984). Sceptcism, Rules, and Language. Blackwell, Oxford.

Dawkins, R. (1994). Burying the Vehicle. Commentary on Wilson \& Sober: Group Selection. Behavioural and Brain Sciences. 17 (4): 616-617.

Dennett, D. (2006). Breaking the Spell: Religion as a Natural Phenomenon. Viking Penguin, NY.

Dietrich, E. (2007). After the Humans are Gone. Philosophy Now, v. 61, May/June, 2007, 16-19.

Dietrich, E. and Hardcastle, V. (2004). Sisyphus's Boulder: Consciousness and the Limits of the Knowable. Amsterdam: John Benjamins.

Gibbard, A. (1975). Contingent Identity, J. of Philosophical logic, 4, 187-221.

Kripke, S. (1980). Naming and Necessity. Harvard University Press, Cambridge, MA.

Kripke, S. (1982). Wittgenstien on Rules and Private Language. Harvard University Press, Cambridge, MA.

McGinn, C. (1984). Wittgenstein on Meaning: An Intepretation and Evaluation. Blackwell, Oxford.

McGinn, C. (1993). Problems in Philosophy: The limits of inquiry. Blackwell, Oxford.

Nagel, T. (1986). The View From Nowhere. Oxford, New York. 
Rozenblit, L., \& Keil, F. (2002). The Misunderstood Limits of Folk Science: An illusion of explanatory depth. Cognitive Science, 26, 521-562.

Shulte, P. et al. (2010). The Chicxulub Asteroid Impact and Mass Extinction at the Cretaceous-Paleogene Boundary. Science, Mar. 5, 2010, v. 327, 1214-1218.

Sober, E. and Wilson, D. S. (1998). Unto Others: The evolution and psychology of unselfish behavior. Harvard University Press, Cambridge, MA.

Sterba, James, (2005). The Triumph of Practice Over Theory in Ethics. Oxford University Press, New York.

Williams, G. C. (1966). Adaptation and Natural Selection: A Critique of Some Current Evolutionary Thought, Princeton University Press, Princeton, NJ.

Wilson, D. S. (1975). A Theory of Group Selection, Proc. Nat. Acad. Sci. 72, (1), 143146.

Wilson, D.S. and Sober, E. (1994). Reintroducing Group Selection to the Human Behavioral Sciences. Behavioral and Brain Sciences 17 (4), 585-654.

Wilson, D. S. and Wilson, E. O. (2008). Evolution "for the good of the group". American Scientist, 96 (5), 380-389. 